This is the author's final version of the work, as accepted for publication following peer review but without the publisher's layout or pagination.

The definitive version is available at:

\title{
A contribution to the conceptualisation of quality in impact assessment
}

Bond, A., Retief, F., Cave, B.*, Fundingsland, M., Duinker, P.N., Verheem, R., Brown, A.L.

* corresponding author

Alan Bond School of Environmental Sciences, University of East Anglia, United Kingdom; Research Unit for Environmental Sciences and Management, North-West University, South Africa. alan.bond@uea.ac.uk

Francois Retief Research Unit for Environmental Sciences and Management, North-West University, South Africa. francois.retief@nwu.ac.za

Ben Cave Ben Cave Associates, United Kingdom; Centre for Primary Health Care and Equity, University of New South Wales, Australia; School of Environmental Sciences, University of Liverpool, United Kingdom. ben.cave@bcahealth.co.uk

Monica Fundingsland, Impact Assessment and Social Performance, Statoil ASA, Norway. mofun@statoil.com

Peter N. Duinker School for Resource and Environmental Studies, Faculty of Management, Dalhousie University, Canada. peter.duinker@dal.ca

Rob Verheem Netherlands Commission for Environmental Assessment, Netherlands. rverheem@eia.nl

A.L. Brown Griffith School of Environment, Griffith University, Brisbane, Australia. lex.brown@griffith.edu.au 


\title{
A contribution to the conceptualisation of quality in impact assessment
}

\begin{abstract}
Quality is much sought after in, and a basic foundation for, good impact assessment (IA). However, the term is rarely defined, has an uncertain relationship with IA effectiveness, and it means different things to different stakeholders, which can lead to debates over the legitimacy associated with an IA process. Thus, IA quality needs conceptualising to position research and practice within broader understandings. This paper contributes to this conceptualisation by identifying nine dimensions of quality through a process of literature review drawing on three fields of study in which quality and quality management have already been debated and conceptualised: education; health care; and business. This approach sidesteps the plural views on quality existing within the field of IA itself which might otherwise bias the identification of quality dimensions. We therefore propose that the dimensions of IA quality are: Efficiency; Optimacy; Conformance; Legitimacy; Equity; Capacity Maintenance; Transformative Capacity; and Quality Management. A literature review of IA research and practice confirms the relevance of the identified quality dimensions to IA. We identify, to an extent, the relationship between quality and effectiveness. Quality aligns with procedural and transactive effectiveness, partly aligns with normative effectiveness and is distinct from, but helps to deliver, substantive effectiveness.
\end{abstract}

\section{Keywords}

impact assessment; quality; effectiveness; conceptualisation; pluralism; dimensions 
Impact Assessment (IA) is an umbrella term for a process (including, amongst others, Environmental Impact Assessment (EIA), Strategic Environmental Assessment (SEA), Health Impact Assessment (HIA), Social Impact Assessment (SIA) and Sustainability Assessment (SA)) that is applied at all levels of decision making and across many sectors (Morrison-Saunders et al., 2014b). IA has been defined as both a technical tool for analysing the consequences of a planned intervention and a legal and institutional procedure linked to the decision-making process of a planned intervention (IAIA, 2010). The process and the outcomes of IA are thus concerned with scientific observation and analysis, with principles of design, with the application of regulations and law, and with the interpretation of local and contextual rights and understandings. IA thus requires a broad range of activities that cuts across sectors and involves multiple stakeholders, each of which has different notions of what good 'quality' means. We seek to conceptualise these notions of quality in IA.

We start by introducing the concept of plurality. Leuschner (2012) analysed the role that pluralism and objectivity each have in scientific research and stated that in "socially, morally, economically or ecologically relevant sciences that have to deal with complex research objects, deliberative instances including a plurality of perspectives are helpful for both moral and epistemic reasons" (p.197). The act of deliberation allows competing perspectives to be assessed and a consensus to be reached. Leuschner (2012) summarised the Kellert et al. (2006) notion of pluralism as involving one or more of a plurality of views over the appropriate theoretical approach to a problem; over the method(s) to apply to examining a problem; there can also be a plurality of people with different perspectives on a problem; and a plurality of people with different value concepts which, in turn, can cause different theoretical or methodological approaches. This analysis can be applied to IA (see section 2 ) in the way that IA involves the application of science to political decision-making and is thus relevant, 'socially, morally, economically or ecologically'; in the way that IA deals with complex research objects, namely the potential effects of a policy, plan, programme or project; and to the way that there is a plurality of views about what IA is expected to deliver to different stakeholders (Glasson et al., 1997; Morrison-Saunders et al., 2001; Bond and Morrison-Saunders, 2011). Fuller (1999) highlighted the different expectations of proponents, the public and decision-makers in relation to the EIA process. This analysis can also be applied to the way that quality is understood in IA as whatever the desired decision outcome for a particular stakeholder, the IA is seen as being one of the determinants of that decision and therefore the quality expectations underpin what the various parties see as being a legitimate decision (Owens et al., 2004).

While there is a plurality of views concerning quality in IA the role that IA plays in underpinning policy decisions, not to mention commercial pressures, means there is a need to manage, and to control, quality in IA and to define and to measure it. Thus, understandings of quality matter as they dictate practice and the changes made to improve practice. This underpins the need for a conceptualisation of quality in IA, so that it is clear how quality can be interpreted, and which dimensions of quality are actually tested and the subject of quality improvement interventions, and which are not. We recognise that taking an approach to conceptualise quality in IA by drawing solely on IA literature has the potential to reproduce any existing biases (i.e. focussing on some understandings of quality at the expense of others), which would be an inappropriate way to frame quality. In this paper we will therefore examine how quality is understood in other fields and explore the applicability of these dimensions to IA. Our first aim is therefore to contribute to a conceptualisation of quality in IA that transcends any potential narrowness in the impact assessment field. 
We are sensitive to the tendency for the terms quality and effectiveness both to be used interchangeably in the IA field. Whilst some authors conflate the terms, many authors have dealt with quality and effectiveness as distinct and exclusive concepts, an understanding which has also provided the basis for criteria and empirical research (for example, Retief, 2007; Lyhne et al., 2015). Further weight is added to the view that quality and effectiveness are distinct concepts by various calls for research on the correlation between the two concepts (Sadler, 1996; Thissen, 2000; Owens et al., 2004; Retief, 2010). Our second aim is therefore to clarify the relationship between quality and effectiveness in IA.

We start with a consideration of the plural nature of quality in section 2 and present evidence for differing perspectives of quality in IA. In section 3 we introduce the methodology through which we contribute both to conceptualising IA quality, and to examining the overlap with IA effectiveness. We unpick the meaning of quality in section 4 , whereby a series of dimensions of quality drawn from fields outside IA are identified (section 4.1). A synthesis of these dimensions is undertaken to produce a single framing of quality based on three fields of research (section 4.2). Section 4.3 examines the relationship between these dimensions of quality and some recognised understandings of effectiveness in IA. In section 5 we examine the extent to which the dimensions are already considered in IA practice and reflected in IA literature. This examination identifies the extent to which the dimensions are already considered in IA practice. Finally, we conclude in section 6 on what this contribution to a conceptualisation of quality in IA might mean for future research and practice and how it can be used to clarify the boundaries for research.

\section{Quality and plurality in IA}

In terms of relevant theory, pluralism is reflected in the diversity of interpretations of quality that exist in the IA literature, and it is acknowledged that the "theoretical indeterminacy is likely to remain a key feature of IA for the foreseeable future" (Cashmore and Kornov, 2013, p.28). A number of authors have made significant contributions to IA theory (for example, Lawrence, 1997; Bartlett and Kurian, 1999; Cashmore, 2004; Richardson, 2005; Fischer, 2007; Weston, 2010; Lobos and Partidario, 2014) which together reflect the plurality of theories that exist in relation to forms of IA. We take, as an example, two models drawn from Bartlett and Kurian (1999), namely the information processing model and the institutionalist model. The information processing model reflects positivist theory, or rationalism, whereby better information leads to better decision-making. Positivist theory is regarded as underpinning the derivation of the world's first EIA legislation - the US National Environmental Policy Act in 1969, albeit the limitations of that theory are increasingly recognised (Weston, 2000). The institutionalist model aims at explaining the difference between the formal process and its practical implementation within institutions (Larsen et al., 2012). In fields like HIA where legal mandates are rare, institutionalisation has been of particular interest as a means of facilitating practice (see, for example, Wismar et al., 2006; Morgan, 2008; Harris and Haigh, 2015). Nykvist and Nilsson (2009) argued that institutional strengthening was more important than process improvement if IA was to deliver the sustainable outcomes sought.

The fact that pluralism can be observed in the variety of methods to apply is reflected within theories. For example, in the context of positivist theory, the quality of the information underpinning and presented in the environmental impact report, has been assessed as the key quality measure in a number of studies using documentary review based on criteria (for example, Lee et al., 1999; Chadwick, 2002; Fischer, 2010; Lindblom, 2012). Practitioner perspectives can also be used as a determinant of quality (Glasson et al., 1997; Morrison-Saunders et al., 2001), as can levels of training and professional recognition (Fuller, 1999). More recently attempts have been 
made to develop approaches for measuring quality including documentary review and interviews to examine more process-related aspects (Bond et al., 2017). And a variety of indices have been developed to examine the quality of the assessment and reporting of environmental impacts (for example, Glasson and Heaney, 1993; Thompson et al., 1997; Chang et al., 2013).

A plurality of people with different perspectives on IA quality was amply illustrated by Fuller (1999) who highlighted three stakeholder groups and their differing expectations for what the EIA process should deliver (Table 1): proponents, public and decision-makers. Petts (1999b) adds local environment groups to her list setting out different stakeholder perspectives on public participation within EIA.

Table 1: $\quad$ Stakeholder expectations of the EIA process (after Fuller, 1999)

\begin{tabular}{|l|l|}
\hline Stakeholder & Key expectations \\
\hline Proponents & $\begin{array}{l}\text { Certainty of outcomes } \\
\text { Cost-effectiveness } \\
\text { Minimisation of delays and adherence to timelines }\end{array}$ \\
\hline Public & $\begin{array}{l}\text { Right to know } \\
\text { Right to be informed } \\
\text { Right to be heard } \\
\text { Right to object }\end{array}$ \\
\hline Decision-makers & $\begin{array}{l}\text { Minimisation of delays and adherence to timelines } \\
\text { Provision of information appropriate for decision-making } \\
\text { Avoidance of unnecessary information } \\
\text { Succinct manageable information }\end{array}$ \\
\hline
\end{tabular}

Evidence of plurality of values comes from research that examines the assessment of quality of environmental impact reports. As noted above this is one interpretation of quality. This research identified that individual reviewers produce statistically different quality ratings than do groups of reviewers (Peterson, 2010). Also, Robinson and Bond (2003) identified statistically different views on aspects of ElA quality between two different local resident communities, and between consultants with different levels of expertise.

Thus, without exploring in detail the different types of pluralism within IA and their relative prevalence, it is clear that all forms of pluralism identified by Leuschner (2012) can be identified in relation to IA quality, which adds to the complication of our search for clarity. We go on to develop an understanding of the dimensions of quality drawn from research on quality in other fields. The quality dimensions are not embedded within any theoretical perspective. This is a deliberate step as we attempt to accommodate all types of pluralism. The dimensions of quality are intended to cut across theories such that, together, they might accommodate all understandings of quality. We consider that further refinement will be needed to ensure the dimensions reflect the particular context of IA processes. For this reason we offer them as a contribution to a conceptualisation of quality in IA and as a starting point for future development.

\section{Conceptualisation method}

Our aims in brief are:

1. to contribute to a conceptualisation of quality; and

2. to clarify the relationship between quality and effectiveness in IA. 
To meet the first of these we follow the approach of Pope et al. (2017) in developing a conceptualisation structured around dimensions; this allows our understanding of IA quality to be disaggregated in order to more easily evaluate.

Learning from other fields is an accepted way to break free of constraining worldviews, and is common in the research literature (see, for example, Keene and Pullin, 2011; Tijhuis et al., 2012). Thus we adopt the approach of undertaking literature review focused on multiple research fields in which conceptualisations of quality have already been developed (section 4.1). These dimensions will then be synthesised to be relevant to the IA field (section 4.2), before going on to evaluate their validity (section 5 ). The validation exercise involves another literature review. The literature identified has then been interrogated through standard techniques to follow useful citations back in time and forward in time, and the authors have drawn on their own expertise to identify additional literature not appearing in the search results.

To meet our second aim, we need to compare our conceptualisation of quality in IA against recognised categories of effectiveness, to examine the relationship between them. As with the term 'quality', so is the term 'effectiveness' highly contested in IA (for example, Cashmore et al., 2004; Bond and Morrison-Saunders, 2013; Harris-Roxas and Harris, 2013). Four broad categories of effectiveness are consistently cited (Chanchitpricha and Bond, 2013): procedural; substantive; transactive; and normative. Whilst each of these can be subdivided into numerous subcategories (see, for example, Chanchitpricha and Bond, 2013) we deliberately adopt the approach of Pope et al. (2015) by simplifying these to facilitate analysis by turning them into simple questions about sustainability assessment (see Table 2).

Table 2: $\quad$ Categories of IA effectiveness (adapted from Pope et al., 2015)

\begin{tabular}{|l|l|}
\hline \multicolumn{1}{|c|}{$\begin{array}{c}\text { Category of } \\
\text { effectiveness }\end{array}$} & \multicolumn{1}{c|}{ Explanation } \\
\hline Procedural & $\begin{array}{l}\text { Have appropriate processes been followed that reflect institutional } \\
\text { and professional standards and procedures? }\end{array}$ \\
\hline Substantive & $\begin{array}{l}\text { In what ways (including cognitively), and to what extent, does IA } \\
\text { lead to changes in process, actions or outcomes? }\end{array}$ \\
\hline Transactive & $\begin{array}{l}\text { To what extent, and by whom, is the outcome of conducting IA } \\
\text { considered to be worth the time and cost involved? }\end{array}$ \\
\hline Normative & $\begin{array}{l}\text { Does the IA meet the expectations of stakeholders irrespective of } \\
\text { the sustainability discourse they align with? }\end{array}$ \\
\hline
\end{tabular}

We evaluate the relationship between effectiveness as set out in Table 2 (recognizing there is no consensus on this) and quality in section 4.3. 


\subsection{Unpicking quality - what it means in other fields of research}

The term 'quality' is applied to different aspects of any given field of practice. For example, in the business literature quality can be framed in terms of quality management (Weckenmann et al., 2015), product quality (Agus, 2005) and business performance (Eccles, 1991). The quality of a given product or service is rarely static. It is instead a dynamic value which is debated and agreed upon among different parties. It is hard-won and easily lost. That is to say, quality is socially constructed. Cidell and Alberts (2006) show this in relation to food quality and Yogev (2009) in relation to art. It is perhaps not surprising that some seek to control how the value of quality is ascribed. Zbaracki (1998) shows how those in charge of delivering quality construct their own understandings of how it should be achieved and whether it is achieved.

We now consider three fields of study and seek to identify from them some dimensions that can be applied to IA: health care; education; and business, because these have been identified as being the key areas of research debate on quality (Harvey and Green, 1993). We assume these three areas remain the key areas of debate, but acknowledge that it is a limitation of our research that we have not systematically analysed the literature to verify the ongoing validity of the assumption.. From a brief examination of literature which synthesised learning in these fields on quality, some commonalities are identified between interpretations of what quality entails (Table 3, Table 4, Table 5 , and Table 6). In each of these fields researchers have already undertaken reviews of quality and conceptualised quality; we draw on highly cited conceptualisations and provide some evidence of the perceived value of our key sources by indicating the citation rates using Scopus in each of these tables. Table 3 focuses on quality as understood in the health care sector.

Table 3: $\quad$ Quality dimensions in health care as defined by (Donabedian, 1990, cited 188 times as at 6 June 2017)

\begin{tabular}{|l|l|}
\hline $\begin{array}{l}\text { Quality } \\
\text { dimension }\end{array}$ & Characteristics of the quality dimension \\
\hline Efficacy & $\begin{array}{l}\text { the ability of health care to bring about improvements in health and well-being } \\
\text { in the best case } \\
\text { the relative nature of solutions - with more expensive solutions producing } \\
\text { greater benefits }\end{array}$ \\
\hline Efficiency & the absolute cost of the required improvements in health and well-being \\
\hline Optimality & the relative consideration of benefits and cost \\
\hline Acceptability & $\begin{array}{l}\text { the extent to which the wishes and expectations of patients and their families } \\
\text { are met, primarily with respect to efficacy, efficiency, and effectiveness }\end{array}$ \\
\hline Legitimacy & $\begin{array}{l}\text { a broader interpretation of acceptability in societal terms rather than for } \\
\text { individuals }\end{array}$ \\
\hline Equity & $\begin{array}{l}\text { what is considered fair or just in terms of distributions of, and access to, health } \\
\text { care }\end{array}$ \\
\hline
\end{tabular}


Based on Table 3, Efficacy differs from effectiveness which is equated to the expected improvement in health and well-being that is typical, rather than best possible (efficacy). In both health and education, the views of the customer or consumer are recognised as a component in the value of any given service. There is a relationship between the institution providing a service or product and a diverse customer base with equally diverse views on that service or product. Efficiency focuses on the cost aspect of delivering the expected value. Optimality looks at costs and benefits in relative terms; it differs from efficiency which gauges ongoing improvements in outcomes in terms of absolute costs only, by examining where the ratio of benefits to costs is highest (optimal). Acceptability and Legitimacy are assessed from the viewpoint purely of the customer. Equity is increasingly protected through legislation, although several strategies are necessary to achieve the goal (Marmot et al., 2008).

Table 4 illustrates how quality is perceived in the education sector.

Table 4: $\quad$ Quality dimensions in education as defined by Harvey and Green (1993, cited 445 times as at 6 June 2017)

\begin{tabular}{|l|l|}
\hline $\begin{array}{l}\text { Quality } \\
\text { dimension }\end{array}$ & Characteristics of the quality dimension \\
\hline Exception & understands quality as being something special (i.e. exceptional) \\
\hline Perfection & focuses on process and expects consistency and excellence \\
\hline $\begin{array}{l}\text { Fitness for } \\
\text { purpose }\end{array}$ & the extent to which a service or product fits its purpose \\
\hline Value for money & $\begin{array}{l}\text { includes notions of efficiency, effectiveness and accountability - such that } \\
\text { fitness for purpose is delivered at least cost, transparently to achieve stated } \\
\text { goals }\end{array}$ \\
\hline Transformative & $\begin{array}{l}\text { recognises that education should both enhance and empower the student (or } \\
\text { other recipient of education) }\end{array}$ \\
\hline
\end{tabular}

For Harvey and Green (1993) Exception is based on the understanding of outcomes as being exceptional - so as good as can be expected; hereafter we use the term 'optimacy' to avoid the potential for misunderstanding arising from more common understanding of the meaning of 'exception' (which is something different as opposed to optimal or exceptional). Perfection relates more to process in being able to consistently achieve the desired outcome; this suggests they do not co-exist in relation to a single element of education as the exception would become the norm in a perfect system! Fitness for purpose reflects the problem of pluralism in that Harvey and Green $(1993$, p.16) are clear "it raises the issue of whose purpose and how is fitness assessed?". Value for money is somewhat complex and, in the context of education, reflects UK Government policy aimed at improving efficiency in higher education (through increasing budgets at a lower rate than increasing student numbers). The Transformative dimension focuses on cognitive change in the user of the education and reflects enhancement of skill sets and the individual taking ownership of their own learning, leading to increased awareness and confidence (Harvey and Green, 1993). 
Agus (2005, cited 56 times as at 6 June 2017) examined quality in the business sector and, specifically, the links between total quality management, product quality and business performance. For the latter, Agus (2005) listed the following criteria: Revenue growth; Sales growth; Market share; Profits; High demand; Product turnover; Productivity; Efficiency. However, we consider that these do not apply to IA in the way we are framing quality in this paper. That is, we are looking at the quality of the process of IA (or system) and not at the financial performance of the service providers. This does constrain how we conceptualise quality and we recognise that the financial viability of service providers is important. Table 5 sets out quality dimensions for total quality management, and Table 6 for product quality.

Table 5: $\quad$ Total Quality Management dimensions adapted from Saraph et al. (1989, cited 1045 times as at 6 June 2017)

\begin{tabular}{|l|l|}
\hline Quality dimension & \multicolumn{1}{|c|}{ Characteristics of the quality dimension } \\
\hline $\begin{array}{l}\text { Management } \\
\text { commitment }\end{array}$ & $\begin{array}{l}\text { the extent to which quality is prioritised by top management and the } \\
\text { level of their commitment to quality goals }\end{array}$ \\
\hline $\begin{array}{l}\text { Quality department } \\
\text { role }\end{array}$ & $\begin{array}{l}\text { expect some autonomy and authority of the quality department in } \\
\text { controlling product }\end{array}$ \\
\hline $\begin{array}{l}\text { Supplier quality } \\
\text { management }\end{array}$ & $\begin{array}{l}\text { quality emphasised rather than price - and quality assurance applied } \\
\text { within suppliers }\end{array}$ \\
\hline Product design & $\begin{array}{l}\text { clear specifications, clear achievability, emphasis on quality rather than } \\
\text { schedule }\end{array}$ \\
\hline Training & $\begin{array}{l}\text { the maintenance of capacity with the organisation to deliver } \\
\text { services/product to an appropriate standard }\end{array}$ \\
\hline Employee focus & $\begin{array}{l}\text { ownership of quality accepted by employees who have open access to } \\
\text { quality decisions }\end{array}$ \\
\hline Process management & clarity of responsibility and fool-proof process design \\
\hline Quality measurement & $\begin{array}{l}\text { relates to the gathering of data in a timely fashion and its use in problem } \\
\text { solving }\end{array}$ \\
\hline
\end{tabular}

The quality dimensions drawn from TQM are relatively self-explanatory although the extent to which they apply will depend on the size of a company - there may be no quality department, for example, although the quality management role would still need to be taken on. Each of management commitment; quality department role; supplier quality management; employee focus; process management; and quality measurement are contingent on a recognition of the importance of quality management and putting in place appropriate systems, and product design expects the systems to deliver outputs which conform with expectations.

Table 6 draws on research into quality in the business field focused on the product made by a company. 
Table 6:

Product quality dimensions as defined by Garvin (1984, cited 668 times as at 6 June 2017)

\begin{tabular}{|l|l|}
\hline Quality dimension & Characteristics of the quality dimension \\
\hline Perceived quality & $\begin{array}{l}\text { Subjective measure of quality based on indirect measures chosen by the } \\
\text { viewer; brand strength has a significant influence }\end{array}$ \\
\hline Conformance & $\begin{array}{l}\text { the degree to which a product matches the design, typically measures by } \\
\text { number of defects }\end{array}$ \\
\hline Performance & $\begin{array}{l}\text { in quality terms reflects customers views in terms of their expectations of } \\
\text { product performance - so subjective }\end{array}$ \\
\hline Reliability & the probability of failure of the product in a specified period of time \\
\hline Durability & $\begin{array}{l}\text { A measure of product life that incorporates repairability. Closely related to } \\
\text { reliability }\end{array}$ \\
\hline Features & $\begin{array}{l}\text { these are secondary characteristics that embellish a product beyond its } \\
\text { expected performance - and again are subjective from a quality standpoint }\end{array}$ \\
\hline Serviceability & $\begin{array}{l}\text { relates to customer satisfaction based on speed, courtesy and competence of } \\
\text { repair, when needed }\end{array}$ \\
\hline Aesthetics & based on personal judgement about how a product appears \\
\hline
\end{tabular}

Not all the dimensions of product quality have relevance for IA given the nature of the product is different. As there is no physical product that customers take home, the dimensions of Durability; Features; Serviceability; and Aesthetics are deemed not to have IA equivalents, although one could conceivably argue that an IA should be durable in terms of the accuracy of predictions and that aesthetics is related to the presentation of information in the report itself. We see that reliability could be considered as being similar to legitimacy in that only a reliable process or product could be trusted. Performance is clearly linked with the normative expectations of various stakeholders, as is the Perceived quality. Conformance relies on some sort of benchmark against which it can be tested.

\subsection{Unpicking quality - a synthesis of quality dimensions with relevance for IA}

Tables 3 to 6 presented quality dimensions as identified in other (non-IA) field of study. We have synthesised these into a single set of dimensions of quality which we believe to be relevant for IA (Table 7). This has involved judgements about the meaning of the words used to describe the dimensions in other fields, in order to combine those with similar meanings into single IA dimensions, and exclude those which we regard as being outside the scope of IA. This step is necessarily judgemental, albeit it draws on the expertise of authors spanning academia, consultancy and an independent advisory organisation. However, we acknowledge that this informed subjectivity remain a limitation of the research which others could dispute. The synthesis is clear on where the various conceptualisations of quality from other fields of study relate to the dimensions identified for IA; and also indicates which dimensions of quality from the other fields of study are not covered with respect to IA (i.e. considered outside its scope).

Of particular note is the fact that we have excluded effectiveness as a dimension of quality. We have set out to examine the relationship between quality and effectiveness which partly explains this 
stance. Section 4.3 will illustrate the relationship between quality and effectiveness which will further justify this exclusion.

Table 7: $\quad$ Proposed dimensions of IA Quality based on other fields of study

\begin{tabular}{|c|c|c|c|c|}
\hline $\begin{array}{c}\text { Dimensions } \\
\text { relevant to IA } \\
\text { Quality }\end{array}$ & $\begin{array}{c}\text { Health care } \\
\text { (Table 3) (after } \\
\text { Donabedian, } \\
\underline{1990)}\end{array}$ & $\begin{array}{l}\text { Education (Table 4) } \\
\text { (after Harvey and } \\
\underline{\text { Green, 1993) }}\end{array}$ & $\begin{array}{c}\text { Total Quality } \\
\text { Management } \\
\text { (Table 5) (after } \\
\text { Saraph et al., } \\
\underline{1989)}\end{array}$ & $\begin{array}{c}\text { Product quality } \\
\text { (Table 6) (after } \\
\text { Garvin, 1984) }\end{array}$ \\
\hline Efficiency & $\begin{array}{l}\text { Efficiency; } \\
\text { Efficacy; } \\
\text { Optimality }\end{array}$ & Value for money & & \\
\hline Optimacy & & Exception & Customer focus & \\
\hline Conformance & & Fitness for purpose & Product design & Conformance \\
\hline \multicolumn{5}{|l|}{ Acceptability } \\
\hline Legitimacy & $\begin{array}{l}\text { Legitimacy; } \\
\text { Acceptability }\end{array}$ & Value for money & Benchmarking & $\begin{array}{l}\text { Reliability; } \\
\text { Perceived } \\
\text { quality; } \\
\text { Performance }\end{array}$ \\
\hline Equity & Equity & & & \\
\hline $\begin{array}{l}\text { Capacity } \\
\text { maintenance }\end{array}$ & & & $\begin{array}{l}\text { Training; } \\
\text { Employee focus }\end{array}$ & \\
\hline $\begin{array}{l}\text { Transformative } \\
\text { capacity }\end{array}$ & & Transformative & & \\
\hline $\begin{array}{l}\text { Quality } \\
\text { management }\end{array}$ & Optimality & Perfection & $\begin{array}{l}\text { Management } \\
\text { commitment; } \\
\text { Quality } \\
\text { department role; } \\
\text { Supplier quality } \\
\text { management; } \\
\text { Employee focus; } \\
\text { Process } \\
\text { management; } \\
\text { Quality } \\
\text { measurement }\end{array}$ & \\
\hline Not covered & Effectiveness & & & $\begin{array}{l}\text { Durability; } \\
\text { Features; } \\
\text { Serviceability; } \\
\text { Aesthetics }\end{array}$ \\
\hline
\end{tabular}


Taking out the duplication between the dimensions identified in section 4.1, this leaves us with the following dimensions of quality against which we indicate how this might be understood in the context of IA:

- Efficiency - the extent to which the best outcomes possible are achieved through an IA process given existing constraints;

- Optimacy - the extent to which the process follows best practice (e.g. international standards) rather than the minimum requirements in any jurisdiction;

- Conformance - the extent to which an IA complies with set requirements;

- Legitimacy - the extent to which individuals and society regard the process and outcomes of an IA as being reliable and acceptable;

- Equity - the extent to which the impacts or benefits identified in an IA, and the steps taken to address the impacts or benefits, are evenly and fairly distributed across society;

- Capacity maintenance - the extent to which the practitioners of IA maintain the skills and knowledge to achieve the other aspects of quality;

- Transformative capacity - the extent to which the IA has empowered individuals or has changed values (institutional or individual) or increased knowledge and/or understanding; and

- Quality management - the extent to which the quality is measured, monitored and managed by those conducting the IA.

There are clearly overlaps in these dimensions. For example, if inequity resulted from an IA, then it would be unlikely to be seen as legitimate.

\subsection{Unpicking quality - its relationship with effectiveness in IA}

We note that Table 7 specifically excluded effectiveness as a dimension of quality in order to facilitate an examination of the relationship between them. This facilitates the identification of the particular relationship we have delivered here. The reason we do not include effectiveness as a dimension of quality is because the literature reveals a much more complex meaning for effectiveness which embraces a broad notion that crosses over the various effectiveness categories listed in Table 2.

Therefore we argue that considering quality as an input to effectiveness, as defined in Table 2, better fits current understandings from the literature. In particular, efficiency relates to transactive effectiveness (Theophilou et al., 2010; Chanchitpricha and Bond, 2013); optimacy and quality management relate to procedural effectiveness (Sadler, 1996; Chanchitpricha and Bond, 2013) whilst legitimacy relates to normative effectiveness (Baker and McLelland, 2003; Chanchitpricha and Bond, 2013). Others are cross-cutting.

Table 3 highlights dimensions of quality from the health sector and includes effectiveness, which is aligned with 'solutions'. This fits with an understanding in IA of this interpretation of effectiveness being aligned with substantive effectiveness. Lawrence (2013) describes 'quality' as being related to inputs to the IA process whereas 'effectiveness' refers to the outputs of the IA process. Based on our analysis, we would tentatively support this view given that we might argue that good quality IA delivers substantive effectiveness, and that different components of quality are closely related, if not 
the same, as procedural, transactive, and some elements of normative, effectiveness. So our conceptualisation of quality focusses on the ex ante component of IA.

\section{The relevance of the proposed quality dimensions to IA Efficiency}

Efficiency refers to the achievement of the best outcomes within reasonable constraints in either of two ways: (a) achieving the best outcome possible given a set of resources and constraints; or (b) given a desired outcome and set of constraints, using the smallest required set of resources for outcome achievement. This dimension understands IA as delivering streamlined processes without jeopardy to the final outcomes, that is achieving 'substantive effectiveness' defined by Sadler (1996, p.39) as: "does the EA process achieve the objectives set, e.g., support well informed decision making and result in environmental protection?".

The threat to the practice of IA through economic recession was recognised by Garner and O'Riordan (1982), and has been argued to explain recent streamlining of legal procedures which have taken place in some jurisdictions; the enforced cost savings raising concerns about the delivery of effective processes (Bond et al., 2014). Thus, efficiency aims to achieve substantive effectiveness at lowest cost. Arguments remain about whether IA provides value for money, with Glasson et al. (2012, p.24) noting a tension between "safety first' policies resulting in too many projects being screened for EIA and the EIA scoping stage being too all embracing of potential impacts". Companies have to balance the risk of court action against the cost of superfluous assessment work. Thus the efficiency of the process is a critical element in this debate. It is contingent on practitioners to spend the least amount possible without jeopardising the substantive effectiveness of the process. Whilst the importance of efficiency is well understood in IA, there remains no method for its measurement.

\section{Optimacy}

Optimacy refers to the best procedures being adopted; this distinguishes it from conformance (explained next) which can reflect 'good enough' if the benchmark used is not optimal. As such we equate this to the many examinations in the literature of 'best practice' which can draw on a number of principles to which practitioners should adhere. A good example is the set of Principles of Environmental Impact Assessment Best Practice produced by the International Association for Impact Assessment and Institute of Environmental Assessment (1999). These can then be considered as the basis, or benchmark, against which the quality of practice can be judged.

Other approaches include the publication of performance standards, for example, the International Finance Corporation (2011) that set out what good practice looks like for EIA. Guidelines for best practice in social impact assessment (SIA) have also been developed (Interorganizational Committee on Principles and Guidelines for Social Impact Assessment, 2003), and for health impact assessment (HIA) (North American HIA Practice Standards Working Group, 2010). These approaches commonly underpin official guidance developed by authorities to assist practitioners in a number of jurisdictions (for example, Department of the Environment Transport and the Regions, 2000; Department of the Environment Transport and the Regions / National Assembly for Wales, 2000; Organisation for Economic Co-operation and Development, 2006).

Best practice can also be identified in relation to particular environmental components (e.g. ecology: Institute of Environmental Assessment and The Landscape Institute, 1995; Marais, 1995) sectors, (e.g. transport: Fischer, 2006) or specific stages (e.g. scoping: Environment Agency, 2002). 'Best 
practice', as yet another social construct, is likely to be contested in terms of quality depending on the framing adopted and the audience at which it is aimed. It is also apparent that the arguments for best practice are different depending on the context, which means that consistency of understanding of quality is hard to deliver across sectors and environmental contexts. Nevertheless, the notion of good-quality IA equating with best practice is enduring in the literature.

In terms of the vast empirical IA report quality review literature, a distinction is often made in the review package and criteria between achieving minimum requirements, in line with legal requirements, and best practice, in line with international and local best practice guidelines (see, for example, Lee and Collev, 1992; Fredsgaard et al., 2009; Sandham et al., 2010). Moreover, the question on how to move practice from minimum requirements and/or business as usual to best practice, or very best outcomes, has been an ongoing debate in IA over the years (see, for example, Morrison-Saunders and Retief, 2012).

\section{Conformance}

Conformance in IA requires legal compliance, and also adherence to Terms of Reference set during the process (e.g. via scoping). Checking conformance infers some kind of ongoing evaluation; for example, Thissen (2000, p.118) states: "there appears to be general agreement in the EA community that a distinction needs to be made between evaluations at the institutional or systems level, and evaluations at the individual project or assessment level." Macro or system evaluations have been one of the earliest themes in IA research reflecting for example on 'enabling conditions' and 'barriers' to the implementation of IA in terms of the policy and legal contexts as well as institutional arrangements (Buckley, 2000; Partidario and Clark, 2000; Stinchcombe and Gibson, 2001).

Principles and criteria for the review of project-level EIA systems have been developed since the early 1990s (Wood, 1995). The ElA systems review criteria developed by Wood have been widely used with adapted versions being applied in developed (Barker and Wood, 1999) and developing countries (Wen-Shyan et al., 1997; Barker and Wood, 1999; Wood and Coppell, 1999; Andreou and Jones, 2001; Ahmad and Wood, 2002). The first macro-level SEA systems review was by Sadler and Verheem (1996) followed by Von Seht (1999) who proposed 15 requirements for a comprehensive SEA system. An extensive SEA system review was conducted by Dalal-Clayton and Sadler (2005) who provided a summary of the status of SEA systems internationally. More recently the Netherlands Commission for Environmental Assessment has set out its conceptualisation of a systems approach to EIA (Netherlands Commission for Environmental Assessment (NCEA), 2014) and to SEA (Netherlands Commission for Environmental Assessment (NCEA), 2014).

Conformance at the individual assessment or project level is often catered for through report quality review which has been embedded in quality review packages (for example, Lee and Colley, 1992; Fredsgaard et al., 2009; Glasson et al., 2012). A second factor: 'Procedural compliance - did the EIA comply with the rules and regulations?'; can be established through the use of oversight agencies, as is the case, for example, in Brazil (Ortolano, 1993), The Netherlands (Wood, 2003) and Western Australia (Morrison-Saunders and Bailey, 2009).

\section{Legitimacy}

Legitimacy is a key consideration for proponents, not least because the realisation of project proposals depends on the ability to secure authority consent and societal approval. This dimension reflects the fact that proponents wish to have a reasonable return on their investments and recognises that significant costs can be incurred where they fail to obtain a social license to operate 
(SLO) (Boutilier, 2014) or through realisation of social and/or environmental risks where IA has inadequately characterised uncertainties (Eduljee, 1999; Petts, 1999a). With increasing stakeholder expectations regarding environmental performance (Retief et al., 2016), the failure to adequately identify and manage environmental and social issues can lead to project delay and overruns, directly affecting financial performance. Adverse environmental and social impacts also have the potential to adversely affect the reputation of both the project and the company. The SLO is therefore important for the effective ongoing management of environmental and social risk (often referred to by proponents as 'non-technical risks') (

Thus, IAs that can act as the means for companies to legitimise projects through SLOs (Bice and Moffat, 2014; Boutilier, 2014) are likely to be viewed as having better quality. This point was made by James Cooney who was credited with popularising the term SLO: "Cooney had noticed that many mining companies were losing money because of community resistance they encountered when they tried to start up new projects or expand existing projects. In order to draw attention to the importance of this source of risk, he likened community opposition to government refusal to issue permits" (Boutilier, 2014, p.263).

SLO overlaps significantly with the term 'Free, Prior and Informed Consent' (FPIC) which is predominantly required (and enshrined to an extent in legal requirements in some jurisdictions) prior to permission being given for projects that will impact on indigenous peoples. There is further overlap with impacts and benefits agreements which communities (not necessarily indigenous) negotiate with developers with no formal mediation (Hanna and Vanclay, 2013). These agreements attempt to formalise the legitimacy of the project.

Legitimacy has thus frequently been the focus of research in the IA field, though Owens et al. (2004) make it clear that legitimacy is secured through assessment practice in different and subtle ways. It remains a dimension of acknowledged importance, but is insufficiently understood.

\section{Equity}

The equity dimension of IA has not been empirically evaluated. The concept of equity features more explicitly in some forms of IA than others, notably in sustainability assessment (Gibson, 2006), HIA (World Health Organization Regional Office for Europe and European Centre for Health Policy, 1999; Quigley et al., 2006) and SIA (Interorganizational Committee on Guidelines Principles for Social Impact Assessment, 1995; Vanclay et al., 2015).

Equity is frequently confused with equality. Equality describes the degree of difference between groups, for example educational attainment, income or health status. This information can be presented without explicit judgement about whether any difference is acceptable. Equity makes the moral and ethical dimension of any difference explicit; it requires that a judgement is made about fairness and justice (see Table 3 and Donabedian (1990)); and it requires a commitment to raise standards for all. There are situations where differences between groups are neither unfair nor unjust so any assessment of equity requires careful definition of the issues, time to deliberate and time for dialogue with affected parties (Knight, 2014).

The timeframe of an assessment means that dialogue with affected parties is not always possible. The notion of equity also applies within, and across, generations (i.e. intra- and intergenerational equity (Bond and Morrison-Saunders, 2011)). Assessments tend to focus on equity within generations as considering equity across generations requires too many assumptions (Bond, 2015). Morrison-Saunders et al. (2014a) recommend that a proper consideration of equity should increase the timeframe of follow-up evaluation to at least two generations (i.e. 50-60 years). The longer 
timeframes also suggest the need for adaptive management approaches to cater for unforeseen changes in societal goals and/or values.

\section{Capacity maintenance}

The need to maintain and develop capacity in IA through training is well recognised (see, for example, Lee, 1988). However, capacity maintenance is a much broader term which also encompasses aspects of accreditation. In the context of education, Harvey $(2004$, p. 207) states that "Accreditation has been described as a public statement that a certain threshold of quality has been achieved or surpassed". Harvey (2004, p.207) characterises institutional accreditation (which, for example, might apply to IA consultancies in the context of IA accreditation) as being usually based "on an evaluation of whether the institution meets specified minimum (input) standards, such as, staff qualifications ...". Such accreditation is typified by various certification schemes that have arisen: China has had an EIA practitioner licensing system since 1986 (Wang et al., 2003); voluntary environmental practitioner certification schemes (rather than EA specifically) also operate in the USA, South Africa, New Zealand, Canada, and the United Kingdom (Woodley and Morgan, 2004); and Flanders (in Belgium) has required compulsory accreditation of experts who work on EIA since 1989 (Charlier, 1996). More recently, the European Union Directive has been amended (European Parliament and the Council of the European Union, 2014) and came into force on $16^{\text {th }}$ May 2017; it introduces a new requirement in Article 5, paragraph 3:

"In order to ensure the completeness and quality of the environmental impact assessment report:

(a) the developer shall ensure that the environmental impact assessment report is prepared by competent experts".

Whilst this wording does not demand certification, the need to ensure competence could be met through certification or accreditation schemes and, therefore, it might reasonably be expected that such schemes will develop in some EU member states (where they do not already exist) either as voluntary or compulsory requirements.

Woodley and Morgan (2004, p.12) recommended that a certification scheme should:

- provide recognition for different levels of EA expertise;

- provide recognition for different types of EA expertise;

- help in defining career pathways and career advancement;

- provide assurance to employers and the public that the EAP [Environmental Assessment Practitioner] has the knowledge and skills to undertake EA:

- provide credibility and accountability to the profession.

They further indicated that different grades should exist associated with continuing professional development requirements.

This dimension is essential for ensuring that the importance of delivering quality is embedded within the mindset of those conducting the assessment - which relates to the 'commitment' dimension drawn from Total Quality Management (Saraph et al., 1989).

\section{Transformative capacity}

Transformative change is considered in IA particularly in the context of learning and public engagement (see, for example, Sinclair and Diduck, 2001; Diduck and Mitchell, 2003; Sims, 2012). 
Jha-Thakur et al. $(2009$, p.134) note that there is a growing recognition of the role of IA in "transforming individual, professional and organisational norms and practices in support of sustainable development". Transformative dimension suggests some change in outlook as well as simple increase in knowledge, and is mirrored in IA research through arguments for a greater focus on the process as an agent of learning (e.g., Ruddy and Hilty, 2008; Jha-Thakur et al., 2009; Nykvist and Nilsson, 2009). And following this line of reasoning, Bond et al. (2013) include learning as a key criterion for the effectiveness of sustainability assessment, against which the quality of national IA systems were assessed (see Gibson, 2013; Morrison-Saunders and Pope, 2013; Retief, 2013; Thérivel, 2013).

Transformation can also mean empowerment, which crosses over with public participation approaches and the extent to which they can empower individuals and or communities. Research is increasingly investigating this aspect of IA process as the basis for good quality (see, for example, Polido et al., 2014; Polido et al., 2016).

The word transformative itself conjures images of change due to the application of impact assessment; this suggests that the practice of IA has achieved something. On this basis alone, this dimension of quality seems highly relevant.

\section{Quality management}

The IA process needs to be managed with quality delivery specifically embedded. This can mean the use of a management system that allocates specific responsibilities for monitoring and checking deliverables. This can be ensured through the incorporation of IA quality requirements into existing accredited quality or environmental management systems (Perdicoúlis and Durning, 2007; Durning, 2014). Vanclay (2004, p.279) highlights that a "significant trend is the mainstreaming of impact assessment considerations through environmental auditing and/or environmental management systems". Indeed, the Quality Mark certification system run in the UK by the Institute of Environmental Management and Assessment (IEMA) specifically requires consultancy companies to have Management Systems accreditation (http://www.iema.net/eia-quality-mark/).

So, this dimension reflects internal management of quality as opposed to conformance which is external. Drawing on TQM literature, it also embeds a need for management and worker commitment (and so has some overlap with capacity maintenance).

\section{Conclusions}

The nature of quality in the context of the pluralism reflected in the practice and expectations of IA means that it is contested. It is important to unpick the understandings of quality so that the relevance of any particular findings or views are clear to all stakeholders. In this paper we have aimed to make a contribution to the conceptualisation of the dimensions of quality by drawing on existing conceptualisations from the fields of health care, education and business (as the key fields of debate on the topic of quality). We have also commented on the relationship of quality with effectiveness.

The conceptualisation is thus somewhat exploratory in that it has not been developed from the IA field itself. However, we would argue that the notions of quality in the IA literature have not been theoretically embedded previously, nor have they sufficiently acknowledged the plural nature of the topic that can lead to contested interpretations. In drawing on literature from three separate fields which have undergone academic debate about the meaning of quality, we tried to be more objective in constructing dimensions of quality that are not embedded in the preconceptions of the authors 
(all from the IA field). The dimensions have been related to IA through analysis of literature, and all have been found to have purchase. We cannot be sure that the dimensions are comprehensive (i.e. some important ones may be missing from our proposed set), and have made no attempt to categorise current investigations of quality in terms of relative focus in existing research. Nor have we made, nor would we make, any attempt to weight the dimensions.

It would be interesting for future research to investigate the extent to which the various dimensions align with discourses on quality associated with different stakeholder groups. Such research would be valuable in deconstructing the pluralism reflected in understandings of quality and could potentially lead to improvements in quality that reflect a multitude of theories on the effectiveness of IA. It would further be important to investigate whether dimensions of quality exist in the IA field which are absent from, or currently unidentified in, the three fields referred to in this research.

Our conceptualisation casts some light on to the confused relationship between effectiveness and quality. Albeit there is no agreed conceptualisation of effectiveness, we suggest that dimensions of quality overlap with procedural effectiveness, transactive effectiveness, and those aspects of normative effectiveness that relate to ex ante IA components. Substantive effectiveness does not overlap and would be delivered by a high-quality IA process. Our research supports the notion that quality provides the input to support effective IA output. Other interpretations are possible from the evidence we have gathered here, but does not match the existing debates in the literature as closely.

Our hope is that in the future, researchers investigating quality will be explicit about the dimensions they are evaluating, and acknowledge the limitations of their work in terms of broader perspectives that might exist. We also hope that knowledge of the dimensions will encourage moves towards quality improvement which are not embedded in limited understandings of quality. We argue that effective IA depends on good quality IA. That is, good inputs lead to good outputs.

\section{References}

Agus, A (2005), "The structural linkages between TQM, product quality performance, and business performance: Preliminary empirical study in electronics companies", Singapore Management Review, 27(1), pages 87.

Ahmad, B and C Wood (2002), "A comparative evaluation of the EIA systems in Egypt, Turkey and Tunisia", Environmental Impact Assessment Review, 22, pages 213-234.

Andreou, A and C Jones (2001), "Development of EIA process in Cyprus", Impact Assessment and Project Appraisal, 19(3), pages 223-233.

Baker, D C and J N McLelland (2003), "Evaluating the effectiveness of British Columbia's environmental assessment process for first nations' participation in mining development", Environmental Impact Assessment Review, 23(5), pages 581-603.

Barker, A and C Wood (1999), "An evaluation of EIA system performance in eight EU countries", Environmental Impact Assessment Review, 19, pages 387404. 
Bartlett, R V and P A Kurian (1999), "The Theory of Environmental Impact Assessment: Implicit models of policy making", Policy \& Politics, 27(4), pages 415-433.

Bice, S and K Moffat (2014), "Social licence to operate and impact assessment", Impact Assessment and Project Appraisal, 32(4), pages 257-262.

Bond, A (2015), "What is the role of impact assessment in the long term?", Journal of Environmental Assessment Policy and Management, 17(1), pages 1550006-1 - 1550006-6.

Bond, A, T B Fischer and J Fothergill (2017), "Progressing quality control in environmental impact assessment beyond legislative compliance: An evaluation of the IEMA EIA Quality Mark certification scheme", Environmental Impact Assessment Review, 63, pages 160-171.

Bond, A and A Morrison-Saunders (2013), "Chapter 3: Challenges in determining the effectiveness of sustainability assessment", in A Bond, A Morrison-Saunders and R Howitt (editors), Sustainability Assessment: Pluralism, Practice and Progress (Taylor and Francis, London) pages 37-50.

Bond, A, A Morrison-Saunders and R Howitt (2013), "Chapter 8: Framework for comparing and evaluating sustainability assessment practice", in A Bond, A Morrison-Saunders and R Howitt (editors), Sustainability Assessment: Pluralism, Practice and Progress (Taylor and Francis, London) pages 117131.

Bond, A, J Pope, A Morrison-Saunders, F Retief and J A E Gunn (2014), "Impact assessment: Eroding benefits through streamlining?", Environmental Impact Assessment Review, 45, pages 46-53.

Bond, A J and A Morrison-Saunders (2011), "Re-evaluating Sustainability Assessment: aligning the vision and the practice", Environmental Impact Assessment Review, 31(1), pages 1-7.

Boutilier, R G (2014), "Frequently asked questions about the social licence to operate", Impact Assessment and Project Appraisal, 32(4), pages 263-272.

Buckley, R (2000), "Strategic Environmental Assessment of policies and plans: legislation and implementation", Impact Assessment and Project Appraisal, 18(3), pages 209-215.

Cashmore, M (2004), "The role of science in environmental impact assessment: process and procedure versus purpose in the development of theory", Environmental Impact Assessment Review, 24(4), pages 403-426.

Cashmore, M, R Gwilliam, R Morgan, D Cobb and A Bond (2004), "The interminable issue of effectiveness: substantive purposes, outcomes and research challenges in the advancement of environmental impact assessment theory", Impact Assessment and Project Appraisal, 22(4), pages 295-310.

Cashmore, M and L Kornov (2013), "Chapter 2: The changing theory of impact assessment", in A Bond, A Morrison-Saunders and R Howitt (editors), Sustainability Assessment: Pluralism, Practice and Progress (Taylor and Francis, London) pages 18-33.

Chadwick, A (2002), "Socio-economic Impacts: Are They Still the Poor Relations in UK Environmental Statements?", Journal of Environmental Planning and Management, 45(1), pages 3-24.

Chanchitpricha, C and A Bond (2013), "Conceptualising the effectiveness of impact assessment processes", Environmental Impact Assessment Review, 43, pages 65-72. 
Chang, T, E Nielsen, W Auberle and F I Solop (2013), "A quantitative method to analyze the quality of EIA information in wind energy development and avian/bat assessments", Environmental Impact Assessment Review, 38, pages $142-150$.

Charlier, R H (1996), "Environmental impact legislation assessments and audits: national legislation and EIA implementation in Belgium", International journal of environmental studies, 51(1), pages 1-19.

Cidell, J L and H C Alberts (2006), "Constructing quality: The multinational histories of chocolate", Geoforum, 37(6), pages 999-1007.

Dalal-Clayton, B and B Sadler (2005), Strategic Environmental Assessment: a sourcebook and reference guide to international experience (Earthscan, London).

Department of the Environment Transport and the Regions (2000), Sustainability appraisal of regional planning guidance: good practice guide (DETR, London) 29.

Department of the Environment Transport and the Regions / National Assembly for Wales (2000), Environmental Impact Assessment. A Guide to Procedures (Thomas Telford Ltd., Tonbridge).

Diduck, A and B Mitchell (2003), "Learning, public involvement and environmental assessment: a Canadian case study", Journal of Environmental Assessment Policy and Management, 5(3), pages 339-364.

Donabedian, A (1990), "The seven pillars of quality", Archives of Pathology and Laboratory Medicine, 114(11), pages 1115-1118.

Durning, B (2014), "Benefits of coupling environmental assessment and environmental management to aid disaster risk reduction and management", Journal of Environmental Assessment Policy and Management, 16(3).

Eccles, R G (1991), "The performance measurement manifesto", Harvard Business Review, 69(1), pages 131-137.

Eduljee, G (1999), "Risk Assessment", in J Petts (editor) Handbook of Environmental Impact Assessment - Vol.1 Environmental Impact Assessment: Process, Methods and Potential (Blackwell Science, Oxford) pages 374-404.

Environment Agency (2002), A handbook for scoping projects (Environment Agency, Bristol).

European Parliament and the Council of the European Union (2014), "Directive 2014/52/EU of the European Parliament and of the Council of 16 April 2014 amending Directive 2011/92/EU on the assessment of the effects of certain public and private projects on the environment", Official Journal of the European Communities, L124, pages 1-18.

Fischer, T (2006), "Strategic environmental assessment and transport planning: towards a generic framework for evaluating practice and developing guidance", Impact Assessment and Project Appraisal, 24(3), pages 183-197.

Fischer, T B (2007), Theory \& Practice of Strategic Environmental Assessment (Earthscan, London).

Fischer, T B (2010), "Reviewing the quality of strategic environmental assessment reports for English spatial plan core strategies", Environmental Impact Assessment Review, 30(1), pages 62-69.

Fredsgaard, M W, B Cave and A Bond (2009), "A review package for Health Impact Assessment reports of development projects", available at $<$ http://bit.ly/k63NtC>, last accessed 29th November 2016. 
Fuller, K (1999), "Quality and Quality Control in Environmental Impact Assessment", in J Petts (editor) Handbook of Environmental Impact Assessment. Volume 2 Environmental Impact Assessment in Practice: Impact and Limitations (Blackwell Science, Oxford) pages 55-82.

Garner, J F and T O'Riordan (1982), "Environmental Impact Assessment in the Context of Economic Recession", The Geographical Journal, 148(3), pages 343-355.

Garvin, D A (1984), "What Does Product Quality Really Mean?", Sloan management review, 26(1), pages 25-43.

Gibson, R B (2006), "Sustainability assessment: basic components of a practical approach", Impact Assessment and Project Appraisal, 24(3), pages 170-182.

Gibson, R B (2013), "Chapter 11: Sustainability assessment in Canada", in A Bond,

A Morrison-Saunders and R Howitt (editors), Sustainability Assessment:

Pluralism, Practice and Progress (Taylor and Francis, London) pages 167183.

Glasson, J and D Heaney (1993), "Socio-economic Impacts: The Poor Relations in British Environmental Impact Statements", Journal of Environmental Planning and Management, 36(3), pages 335-343.

Glasson, J, R Therivel and A Chadwick (2012), Introduction to Environmental Impact Assessment (Routledge, London).

Glasson, J, R Therivel, J Weston, E Wilson and R Frost (1997), "EIA - Learning from Experience: Changes in the Quality of Environmental Impact Statements for UK Planning Projects", Journal of Environmental Planning and Management, 40(4), pages 451-464.

Hanna, P and F Vanclay (2013), "Human rights, Indigenous peoples and the concept of Free, Prior and Informed Consent", Impact Assessment and Project Appraisal, 31(2), pages 146-157.

Harris-Roxas, B and E Harris (2013), "The impact and effectiveness of health impact assessment: A conceptual framework", Environmental Impact Assessment Review, 42, pages 51-59.

Harris, P J and F Haigh (2015), "Including health in environmental impact assessments: is an institutional approach useful for practice?", Impact Assessment and Project Appraisal, 33(2), pages 135-141.

Harvey, L (2004), "The power of accreditation: views of academics 1", Journal of Higher Education Policy and Management, 26(2), pages 207-223.

Harvey, L and D Green (1993), "Defining quality", Assessment \& evaluation in higher education, 18(1), pages 9-34.

Hoff, M, J Das, S Murfitt and A Martin (2015), " Effective management of ESG risks in major infrastructure projects", in J Altman (editor) Infrastructure Risk Management (PEI, London) pages 47-55.

IAIA (2010), What is impact assessment? (International Association for Impact Assessment, Fargo, ND, USA).

Institute of Environmental Assessment and The Landscape Institute (1995), Guidelines for Landscape and Visual Impact Assessment (E \& FN Spon, London).

International Association for Impact Assessment and Institute of Environmental Assessment (1999), "Principles of Environmental Impact Assessment Best Practice", available at <http://iaia.org/publicdocuments/specialpublications/Principles\%20of\%20IA web.pdf>, last accessed 27 November 2013. 
International Finance Corporation (2011), "IFC Performance Standards on Environmental and Social Sustainability - Effective January 1, 2012", available at

$<$ http://www1.ifc.org/wps/wcm/connect/c8f524004a73daeca09afdf998895a12/ IFC Performance Standards.pdf?MOD=AJPERES $>$, last accessed 4th June 2013.

Interorganizational Committee on Guidelines Principles for Social Impact Assessment (1995), "Guidelines and Principles for Social Impact

Assessment", Environmental Impact Assessment Review, 15, pages 11-43.

Interorganizational Committee on Principles and Guidelines for Social Impact Assessment (2003), "Principles and guidelines for social impact assessment in the USA", Impact Assessment and Project Appraisal, 21(3), pages 231-250.

Jha-Thakur, U, P Gazzola, D Peel, T B Fischer and S Kidd (2009), "Effectiveness of strategic environmental assessment - the significance of learning", Impact Assessment and Project Appraisal, 27(2), pages 133-144.

Keene, M and A S Pullin (2011), "Realizing an effectiveness revolution in environmental management", Journal of Environmental Management, 92(9), pages 2130-2135.

Kellert, S, H Longino and K Waters (2006), "Introduction: The pluralist stance", in S Kellert, $\mathrm{H}$ Longino and K Waters (editors), Scientific pluralism (University of Minnesota Press., Minneapolis) pages vii-xxix.

Knight, E K (2014), "Shifting public health practice to advance health equity: recommendations from experts and community leaders", J Public Health Manag Pract, 20(2), pages 188-96.

Larsen, S V, L Kørnøv and A Wejs (2012), "Mind the gap in SEA: An institutional perspective on why assessment of synergies amongst climate change mitigation, adaptation and other policy areas are missing", Environmental Impact Assessment Review, 33(1), pages 32-40.

Lawrence, D P (1997), "The need for EIA theory-building", Environmental Impact Assessment Review, 17, pages 79-107.

Lawrence, D P (2013), Impact Assessment: Practical Solutions to Recurrent Problems and Contemporary Challenges (John Wiley \& Sons, New Jersey).

Lee, $N$ (1988), "Training requirements for environmental impact assessment", in $P$ Wathern (editor) Environmental Impact Assessment: Theory and Practice (Routledge, London) pages 143-158.

Lee, N and R Colley (1992), "Reviewing the Quality of Environmental Statements. Second edition.", Occasional Paper Number 24.

Lee, N, R Colley, J Bonde and J Simpson (1999), Reviewing the Quality of Environmental Statements and Environmental Appraisals. Occasional Paper 55 (EIA Centre, University of Manchester, Manchester) 72.

Leuschner, A (2012), "Pluralism and objectivity: Exposing and breaking a circle", Studies in History and Philosophy of Science Part A, 43(1), pages 191-198.

Lindblom, I (2012), "Quality of Cultural Heritage in EIA; twenty years of experience in Norway", Environmental Impact Assessment Review, 34, pages 51-57.

Lobos, V and M Partidario (2014), "Theory versus practice in Strategic Environmental Assessment (SEA)", Environmental Impact Assessment Review, 48, pages 34-46.

Lyhne, I, M Cashmore, H Runhaar and F van Laerhoven (2015), "Quality Control for Environmental Policy Appraisal Tools: An Empirical Investigation of Relations 
Between Quality, Quality Control and Effectiveness", Journal of Environmental Policy \& Planning, (ahead-of-print), pages 1-20.

Marais, M (1995), "Guidelines for Baseline Ecological Assessment", Environmental Assessment, 3(2), pages 62.

Marmot, M, S Friel, R Bell, T A Houweling, S Taylor and C o S D o Health (2008), "Closing the gap in a generation: health equity through action on the social determinants of health", The Lancet, 372(9650), pages 1661-1669.

Morgan, R K (2008), "Institutionalising health impact assessment: the New Zealand experience", Impact Assessment and Project Appraisal, 26(1), pages 2-16.

Morrison-Saunders, A, D Annandale and J Cappelluti (2001), "Practitioner perspectives on what influences EIA quality", Impact Assessment and Project Appraisal, 19(4), pages 321-325.

Morrison-Saunders, A and M Bailey (2009), "Appraising the role of relationships between regulators and consultants for effective EIA", Environmental Impact Assessment Review, 29(5), pages 284-294.

Morrison-Saunders, A and J Pope (2013), "Chapter 10: Learning by doing: sustainability assessment in Western Australia", in A Bond, A MorrisonSaunders and R Howitt (editors), Sustainability Assessment: Pluralism, Practice and Progress (Routledge, London) pages 149-166.

Morrison-Saunders, A, J Pope, A Bond and F Retief (2014a), "Towards sustainability assessment follow-up", Environmental Impact Assessment Review, 45, pages 38-45.

Morrison-Saunders, A, J Pope, J Gunn, A Bond and F Retief (2014b), "Strengthening impact assessment: a call for integration and focus", Impact Assessment and Project Appraisal, 32(1), pages 2-8.

Morrison-Saunders, A and F Retief (2012), "Walking the sustainability assessment talk - Progressing the practice of environmental impact assessment (EIA)", Environmental Impact Assessment Review, 36, pages 34-41.

Netherlands Commission for Environmental Assessment (NCEA) (2014), "A systems approach to EIA Effectiveness", available at

$<$ http://api.commissiemer.nl/docs/mer/diversen/ncea system approach eia d ef.pdf>, last accessed 14 December 2015.

North American HIA Practice Standards Working Group (2010), Minimum Elements and Practice Standards for Health Impact Assessment (HIA) (North American HIA Practice Standards Working Group, Oakland, California, United States).

Nykvist, B and M Nilsson (2009), "Are impact assessment procedures actually promoting sustainable development? Institutional perspectives on barriers and opportunities found in the Swedish committee system", Environmental Impact Assessment Review, 29(1), pages 15-24.

Organisation for Economic Co-operation and Development (2006), Applying Strategic Environmental Assessment. Good Practice Guidance for Development Co-operation (OECD Publishing, Paris).

Ortolano, L (1993), "Controls on project proponents and environmental impact assessment effectiveness", Environmental Professional, 15(4), pages 352363.

Owens, S, T Rayner and O Bina (2004), "New agendas for appraisal: reflections on theory, practice, and research", Environment and Planning A, 36(11), pages 1943-1959.

Partidario, M and R Clark (2000), Perspectives on Strategic Environmental Assessment (CRC Press, Boca Raton). 
Perdicoúlis, A and B Durning (2007), "An alternating-sequence conceptual framework for EIA-EMS integration", Journal of Environmental Assessment Policy and Management, 9(4), pages 385-397.

Peterson, K (2010), "Quality of environmental impact statements and variability of scrutiny by reviewers", Environmental Impact Assessment Review, 30(3), pages 169-176.

Petts, J (1999a), "Environmental Impact Assessment versus other Environmental Management Tools", in J Petts (editor) Handbook of Environmental Impact Assessment - Vol.1 Environmental Impact Assessment: Process, Methods and Potential (Blackwell Science, Oxford) pages 33-59.

Petts, J (1999b), "Public participation and environmental impact assessment", in $\mathrm{J}$ Petts (editor) Handbook of Environmental Impact Assessment - Vol.1 Environmental Impact Assessment: Process, Methods and Potential (Blackwell Science, Oxford) pages 145-177.

Polido, A, E João and T B Ramos (2014), "Sustainability approaches and strategic environmental assessment in small islands: An integrative review", Ocean and Coastal Management, 96, pages 138-148.

Polido, A, E João and T B Ramos (2016), "Exploring experts' views and perspectives on the enhancement of Strategic Environmental Assessment in European small islands", Environmental Impact Assessment Review, 58, pages 25-33.

Pope, J, A Bond, J Hugé and A Morrison-Saunders (2017), "Reconceptualising sustainability assessment", Environmental Impact Assessment Review, 62, pages 205-215.

Pope, J, A Bond and A Morrison-Saunders (2015), "Chapter 18: Conclusion: Reflections on the State of the Art of Sustainability Assessment", in A Morrison-Saunders, J Pope and A Bond (editors), Handbook of Sustainability Assessment (Edward Elgar, Cheltenham, UK and Northampton, USA) pages 427-454.

Quigley, R, L den Broeder, P Furu, A Bond, B Cave and R Bos (2006), Health Impact Assessment (International Association for Impact Assessment).

Retief, F (2007), "A quality and effectiveness review protocol for strategic environmental assessment (SEA) in developing countries", Journal of Environmental Assessment Policy and Management, 9(4), pages 443-471.

Retief, $\mathrm{F}$ (2010), "The Evolution of Environmental Assessment Debates: Critical Perspectives from South Africa", Journal of Environmental Assessment Policy and Management, 12(4), pages 375-397.

Retief, F (2013), "Chapter 12: Sustainability assessment in South Africa", in A Bond, A Morrison-Saunders and R Howitt (editors), Sustainability Assessment: Pluralism, Practice and Progress (Taylor and Francis, London) pages 184196.

Retief, F, A Bond, J Pope, A Morrison-Saunders and N King (2016), "Global megatrends and their implications for Environmental Assessment (EA) practice", Environmental Impact Assessment Review, 61, pages 52-60.

Richardson, T (2005), "Environmental assessment and planning theory: four short stories about power, multiple rationality, and ethics", Environmental Impact Assessment Review, 25(4), pages 341-365.

Robinson, M and A Bond (2003), "Investigation of Different Stakeholder Views of Local Resident Involvement during Environmental Impact Assessments in the UK", Journal of Environmental Assessment Policy and Management, 5(1), pages $45-82$. 
Ruddy, T F and L M Hilty (2008), "Impact assessment and policy learning in the European Commission", Environmental Impact Assessment Review, 28(2-3), pages 90-105.

Sadler, B (1996), International Study of the Effectiveness of Environmental Assessment Final Report - Environmental Assessment in a Changing World: Evaluating Practice to Improve Performance. (Minister of Supply and Services Canada, Ottawa) 248.

Sandham, L A, T H Carroll and F P Retief (2010), "The contribution of Environmental Impact Assessment (EIA) to decision making for biological pest control in South Africa - The case of Lantana camara", Biological Control, 55(2), pages 141-149.

Saraph, J V, P G Benson and R G Schroeder (1989), "An Instrument for Measuring the Critical Factors of Quality Management", Decision Sciences, 20(4), pages 810-829.

Sims, L (2012), "Taking a learning approach to community-based strategic environmental assessment: Results from a Costa Rican case study", Impact Assessment and Project Appraisal, 30(4), pages 242-252.

Sinclair, A J and A P Diduck (2001), "Public involvement in EA in Canada: a transformative learning perspective", Environmental Impact Assessment Review, 21(2), pages 113-136.

Stinchcombe, K and R Gibson (2001), "Strategic Environmental Assessment as a means of pursuing sustainability: Ten advantages and ten challenges", Journal of Environmental Assessment Policy and Management, 3(3), pages 343-372.

Theophilou, V, A Bond and M Cashmore (2010), "Application of the SEA Directive to EU structural funds: perspectives on effectiveness", Environmental Impact Assessment Review, 30(2), pages 136-144.

Thérivel, R (2013), "Chapter 9: Sustainability assessment in England", in A Bond, A Morrison-Saunders and R Howitt (editors), Sustainability Assessment: Pluralism, Practice and Progress (Taylor and Francis, London) pages 132148.

Thissen, W (2000), "Criteria for the evaluation of SEA", in M Partidario and R Clark (editors), Perspectives on SEA (CRC Press, Boca Raton) pages 113-127.

Thompson, S, J R Treweek and D J Thurling (1997), "The Ecological Component of Environmental Impact Assessment: A Critical Review of British Environmental Statements", Journal of Environmental Planning and Management, 40(2), pages 157-171.

Tijhuis, M J, M V Pohjola, H Gunnlaugsdóttir, N Kalogeras, O Leino, J M Luteijn, S H Magnússon, G Odekerken-Schröder, M Poto, J T Tuomisto, Ø Ueland, B C White, F Holm and H Verhagen (2012), "Looking beyond borders: Integrating best practices in benefit-risk analysis into the field of Food and Nutrition", Food and Chemical Toxicology, 50(1), pages 77-93.

Vanclay, F (2004), "The Triple Bottom Line and Impact Assessment: How do TBL, EIA, SIA, SEA and EMS relate to each other?", Journal of Environmental Assessment Policy and Management, 6(3), pages 265-288.

Vanclay, F, A M Esteves, I Aucamp and D Franks (2015), Social Impact Assessment: Guidance for assessing and managing the social impacts of projects (International Association for Impact Assessment, Fargo ND).

Von Seht, H (1999), "Requirements of a comprehensive strategic environmental assessment system", Landscape and Urban Planning, 45, pages 1-14. 
Wang, Y, R K Morgan and M Cashmore (2003), "Environmental impact assessment of projects in the People's Republic of China: new law, old problems", Environmental Impact Assessment Review, 23(5), pages 543-579.

Weckenmann, A, G Akkasoglu and T Werner (2015), "Quality management - History and trends", TQM Journal, 27(3), pages 281-293.

Wen-Shyan, L, W Williams and A Bark (1997), "Evaluation of environmental impact assessment in three Southeast Asian nations", Project Appraisal, 12(2), pages 89-100.

Weston, J (2000), "EIA, Decision-making Theory and Screening and Scoping in UK Practice", Journal of Environmental Planning and Management, 43(2), pages 185-203.

Weston, J (2010), "EIA Theories - All Chinese Whispers and No Critical Theory", Journal of Environmental Assessment Policy and Management, 12(4), pages 357-374.

Wismar, M, J Blau, K Ernst, E Elliot, A Golby, L van Herten, T Lavin, M Stricka and G Williams (2006), "Implementing and institutionalizing health impact assessment in Europe", in T Ståhl, M Wismar, E Ollila, E Lahtinen and K Leppo (editors), Health in All Policies: Prospects and potentials (Finnish Ministry of Social Affairs and Health) pages 231-252.

Wood, C (1995), Environmental Impact Assessment: A Comparative Review (Longmann Scientific \& Technical, Harlow).

Wood, C (2003), Environmental Impact Assessment: A Comparative Review (Prentice Hall, Edinburgh).

Wood, C and L Coppell (1999), "An evaluation of the Hong Kong environmental impact assessment system", Impact Assessment and Project Appraisal, 19(1), pages 21-31.

Woodley, D and R K Morgan (2004), Certification of Environmental Assessment Practitioners: A Recommended Scheme for Developing Countries (Centre for Impact Assessment Research and Training, Dunedin) 19.

World Health Organization Regional Office for Europe and European Centre for Health Policy (1999), Health impact assessment: main concepts and suggested approach. Gothenburg consensus paper (WHO Regional Office for Europe, ECHP, Brussels) 1-10.

Yogev, T (2009), "The social construction of quality: Status dynamics in the market for contemporary art", Socio-Economic Review, 8(3), pages 511-536.

Zbaracki, M J (1998), "The rhetoric and reality of total quality management", Administrative Science Quarterly, 43(3), pages 602-636. 